\title{
MiRNA-29a regulates the expression of numerous proteins and reduces the invasiveness and proliferation of human carcinoma cell lines
}

\author{
M.K. Muniyappa, P. Dowling, M. Henry, P. Meleady, P. Doolan, P. Gammell, M. Clynes, \\ N. Barron *
}

National Institute for Cellular Biotechnology, Dublin City University, Dublin 9, Ireland

\section{A R T I C L E I N F O}

Article history:

Received 25 June 2009

Received in revised form 31 August

2009

Accepted 11 September 2009

Available online 7 October 2009

Keywords:

In vitro invasion

microRNA

Proteomic profiling

Lung cancer

$\operatorname{miR}-29 a$

\begin{abstract}
A B S T R A C T
In this study we have identified a functional role for miR-29a in cancer cell invasion and proliferation. MiRNA expression profiling of human NSCLC cell lines indicated that miR$29 a$ levels were reduced in more invasive cell lines. Exogenous overexpression of miR-29a in both lung and pancreatic cancer cell lines resulted in a significant reduction in the invasion phenotype, as well as in proliferation. 2D DIGE proteomic profiling of cells transfected with pre-miR-29a or anti-miR-29a resulted in the identification of over 100 differentially regulated proteins. The fold change of protein expression was generally modest - in the range 1.2-1.7-fold. Only 14 were predicted computationally to have miR-29a seed sequences in their 3' UTR region.

Subsequent studies using siRNA to knock down several candidate proteins from the 2D DIGE experiment identified RAN (a member of the RAS oncogene family) which significantly reduced the invasive capability of a model lung cancer cell line.

We conclude that miR-29a has a significant anti-invasive and anti-proliferative effect on lung cancer cells in vitro and functions as an anti-oncomir. This function is likely mediated through the post-transcriptional fine tuning of the cellular levels of several proteins, both directly and indirectly, and in particular we provide some evidence that RAN represents one of these.
\end{abstract}

(c) 2009 Elsevier Ltd. All rights reserved.

\section{Introduction}

MicroRNAs have emerged in recent years as key regulators in a broad spectrum of cellular functions - and dysfunctions - as evidenced by the proliferation of reports in the literature relating to their study. A large proportion of these have been in the field of cancer research with several focused on the invasive/metastatic process specifically. ${ }^{1}$

One of the challenges of studying miRNA function in the cellular environment is identifying potential protein targets. Many early studies started with the target gene, often well associated with some aspect of cancer, and then tried to identify miRNAs that might bind the transcript based on in silico predictions. ${ }^{2,3}$ Conversely, in silico analysis has been used to predict the potential target genes based on the sequence of a particular miRNA. ${ }^{4}$ The rules being used to develop these algorithms are becoming more refined as experimental data builds, leading to improved predictive capacity of these software tools. More recently, high throughput proteomic and transcriptomic technologies have greatly increased the identification and understanding of bona fide miRNA targets in cell lines, tissue samples and in vivo. ${ }^{5}$

\footnotetext{
* Corresponding author: Tel.: +35 317005804; fax: +35 317005484 .

E-mail address: niall.barron@dcu.ie (N. Barron).
} 
In this study we were interested in identifying downstream targets of miR-29a using such approaches. MiR-29a is found on chromosome 7q32.3 in tandem with miR-29b-1 and has been reported in studies focused on cancer biomarker identification ${ }^{6}$ as well as cancer-related phenotypes in vitro and in vivo. It has been shown to regulate the levels of Mcl-1 and subsequently increase TRAIL-mediated apoptosis in malignant cholangiocarcinoma cells. ${ }^{3}$ TCL-1, the oncogene implicated in progression of CLL, has been shown to be regulated, at least in part, by the action of miR-29a. ${ }^{7}$ In lung cancer cell lines $\mathrm{miR}-29 a$ was shown to reverse aberrant methylation by down-regulating the expression of DNMT3A and $3 \mathrm{~B}^{4}$ Importantly, a study by Chang and colleagues demonstrated that $m i R-29 a$ is a target for suppression by c-myc. ${ }^{8}$ Preliminary work in our laboratory identified miR-29a as being differentially expressed in an in vitro model of invasive lung cancer. In combination these findings point to an important role for this molecule in maintaining normal cellular function and behaviour and prompted us to further investigate other potential target proteins and pathways influenced by $m i R-29 a$ in our model system.

\section{Materials and methods}

\subsection{Cell culture}

Lung carcinoma cell lines, DLKP and DLKP- $\mathrm{A}^{9}$ were maintained in ATCC media supplemented with 5\% FCS and incubated at $37^{\circ} \mathrm{C}$. DLKP is a poorly differentiated, squamous cell lung carcinoma with a non-invasive phenotype. DLKP-A is a highly invasive variant generated by chronic exposure of the parent cell line to the chemotherapeutic drug, Adriamycin. PANC-1 cell line is a highly invasive cell line derived from a pancreatic ductal carcinoma (ATCC) and maintained in DMEM supplemented with $5 \%$ (v/v) FCS and incubated at $37^{\circ} \mathrm{C}$.

\subsection{Transfection of cells}

The cells were transfected in suspension after trypsinisation with $50 \mathrm{nM}$ siRNA, anti-miR or pre-miR (Applied Biosystems). For the invasion assay, $3 \times 10^{5}$ cells per millilitre were transfected per well of a 24 -well plate. For proliferation, $3 \times 10^{4}$ cells were seeded per well of a $96-w$ plate. Transfection complexes were prepared in OptiMEM (Invitrogen) with $0.15 \mu \mathrm{l} / 96$ well or $2 \mu \mathrm{l} / 24$-well of siPORT NeoFx transfection agent (Ambion). Seventy-two hours post-transfection, the cells were lysed for qRT-PCR analysis or Western blot, and assayed for proliferation or used to seed an in vitro invasion assay. For stable plasmid transfections $2 \mu \mathrm{g}$ DNAs were used to transfect $3 \times 10^{5}$ cells in $2 \mathrm{ml}$ in a 6 -well plate. Forty-eight hours post-transfection the medium was supplemented with $800 \mu \mathrm{g} / \mathrm{ml} \mathrm{G418}$ and selection was continued until the mock-transfected cells were killed. Surviving cells were expanded and single-cell cloned by the limiting dilution method.

\subsection{Detection of mature miR-29a by $q R T-P C R$}

MiR-29a quantification was performed according to the primer/probe assay protocol provided by the manufacturer (Ap- plied Biosystems). For the RT step, $25 \mathrm{ng}$ RNA was used to generate cDNA. Quantitative PCR was performed by the addition of $2 \times$ Taqman Universal Mastermix containing the appropriate probe/primer mix. RNU6B expression was used for internal normalisation. All reactions were performed on an AB7500 instrument and relative expression was calculated using the $2^{-\Delta \Delta C t}$ method in SDS 1.3 software.

\subsection{In vitro proliferation and invasion assay}

The cell numbers were assessed $72 \mathrm{~h}$ post-transfection using the acid phosphatase method. ${ }^{10}$ Invasion assays were performed using Matrigel ${ }^{\text {ms }}$ invasion assays (BD Bioscience). After rehydration of the matrix, the medium underneath the insert was replaced with ATCC media containing 5\% (v/v) FCS. Seventy-two hours after miRNA/siRNA transfections, the cells were trypsinised, counted and resuspended in media containing $5 \%(\mathrm{v} / \mathrm{v})$ FCS at a density of $1 \times 10^{6} \mathrm{cells} / \mathrm{ml}$. Hundred microlitres of cell suspension was added to each insert. The cells were incubated at $37^{\circ} \mathrm{C}$ for $24-48 \mathrm{~h}$, after which the inserts were stained, washed and the number of invasive cells were determined by counting 10 random fields at $20 x$ magnification.

\subsection{Detection of mRNA levels of siRNA knockdown gene targets}

RNA was isolated from post-siRNA-transfected cells using the RNeasy Mini Prep Kit ${ }^{\circledR}$ (Qiagen) and quantified using a Nanodrop $^{m}$ spectrophotometer. For each reaction 500 ng RNA was used to generate cDNA using a high-capacity cDNA reverse transcription kit (Applied Biosystems). SybrGreen ${ }^{\mathrm{m}}$-based qRT-PCR analysis was performed with specific primers designed for each target. Primers used were (a) RAN (sense 5'-GTTGGTGATGGTGGTACTGGAA-3', antisense 5'-TCCTCTGTTGGTGTGGAACACT-3') and (b) B-actin (sense5'-AGCAGGAGTATGACGAGTCCG-3', antisense 5'-TCCCAGGGAGACCAAAAGC-3'). Each PCR contained $400 \mathrm{nM}$ of sense and antisense primers and $50 \mathrm{ng}$ of cDNA. There were technical as well as biological triplicates of each sample. Target gene expression levels were normalised using $\beta$-actin.

\subsection{Plasmid constructs}

The miR-29a expression vector was constructed by PCR amplification of $\sim 250$ bp sequence from DLKP genomic DNA. This contained the complete pre-miR-29a sequence and additional sequence upstream and downstream. The primers used were sense 5'-AAACCGGATCCGAGCCCAATGTATGCTGGATTTAG-3' (BamHI site underlined) and antisense 5'-CCCAACTCGAGTTAAGCTTTGTTTTCTTAGTTCTTGTCCATGG-3' (HindIII site underlined). PCR amplification was performed with KOD-XL High Fidelity PCR kit (Merck/Novagen), using $0.7 \mu \mathrm{g}$ template in a $50 \mu \mathrm{l}$ reaction mixture, according to the manufacturers protocol. Thermal cycler conditions were $95^{\circ} \mathrm{C}$ for $2 \mathrm{~min}$, followed by 30 cycles of $94^{\circ} \mathrm{C}$ for $30 \mathrm{~s}, 60^{\circ} \mathrm{C}$ for $5 \mathrm{~s}$ and $72{ }^{\circ} \mathrm{C}$ for $30 \mathrm{~s}$. The PCR product was digested with BamHI/HindIII and ligated into pSilencer ${ }^{\mathrm{TM}}$ 4.1-CMV-Neo vector (Ambion).

The RAN 3' UTR sequence was amplified from DLKP-A-derived total RNA using custom primers: sense 5'- 
AAAAAGCTTTGAGAATGAAGCTGGAGCCCAG-3' (HindIII site underlined) and antisense 5'-CCCGGATCCCGGCTTGCGTATCAACT TCACA-3' (BamHI site underlined). The amplified PCR product was digested with HindIII/BamHI and cloned downstream of $g f p$ in $\mathrm{pEGFP-C1}$ vector (Clontech).

\section{2D Difference gel electrophoresis (2D DIGE)}

DLKP-A cells were transfected with pre-miR-29a, anti-miR-29a or their negative controls for $72 \mathrm{~h}$ and harvested. Lysates were minimally labelled with $200 \mathrm{pmol} / 50 \mu \mathrm{g}$ of protein with either Cy3 (control) or Cy5 (test) for comparison on the same gel (dyes from GE Healthcare). A pool containing equal amounts of all samples was also prepared and labelled with Cy2 to be used as an internal standard on all gels to aid image matching and cross-gel statistical analysis. Three biological repeats of each transfected sample were preformed. Twelve gels were generated in total, with two gels per comparison.

Immobilised $24 \mathrm{~cm}$ linear $\mathrm{pH}$ gradient (IPG) strips (GE Healthcare), $\mathrm{pH}$ 3-11, were rehydrated in rehydration buffer (7 M urea, $2 \mathrm{M}$ thiourea, 4\% CHAPS, 0.5\% IPG Buffer, $50 \mathrm{mM}$ DTT) overnight. 2D DIGE was performed according to the manufactures instructions and as previously described. ${ }^{11}$ The gels were scanned with a Typhoon variable mode imager (GE Healthcare) and the subsequent gel images were imported into the BVA module of DeCyder 6.5 software. Proteins were defined as differentially regulated if the observed fold change was $\pm 1.2(p<0.05)$ in 1 -WAY ANOVA between negative and pre- or anti-miR-29a-treated samples.

\subsection{Protein identification by mass spectrometry}

Protein digestion and MALDI-TOF MS were performed as described previously. ${ }^{11}$ For MALDI-TOF MS analysis, protein identification was achieved using the PMF Profound database search engine for peptide mass fingerprints. Low abundance proteins were identified using LC-MS/MS with an Ettan MDLC system (GE Healthcare) in high throughput configuration directly connected to a Finnegan LTQ (Thermo Electron). The peptides were concentrated and desalted on RPC trap columns (Zorbax 300SB C18, $0.3 \mathrm{~mm} \times 5 \mathrm{~mm}$, Agilent Technologies), and were separated on a nano-RPC column (Zorbax 300SB C18, $0.075 \mathrm{~mm} \times 100 \mathrm{~mm}$, Agilent Technologies) using a linear acetonitrile gradient from $0 \%$ to $65 \%$ over $60 \mathrm{~min}$. All buffers used for nano LC separation contained $0.1 \%$ formic acid (Fluka) as the ion-pairing reagent. Full scan mass spectra were recorded in profile mode and tandem mass spectra in centroid mode. The peptides were identified using the information in the tandem mass spectra by searching against the SWISS PROT database using SEQUEST.

\subsection{Criteria for protein identification}

For protein identification, artificial modifications of peptides (carbamidomethylation of cysteines and partial oxidation of methionines) were considered. Searches were also carried out allowing for one missed cleavage. Protein identifications were accepted if they could be established at greater than $99.8 \%$ probability and had at least two identified peptides.

\subsection{Western blotting}

Western blotting was performed on protein cell lysates (7 M urea, $2 \mathrm{M}$ thiourea, $4 \%$ CHAPS, $30 \mathrm{mM}$ Tris/HCl, $\mathrm{pH}$ 8.5) with $20 \mu \mathrm{g} /$ lane of protein separated on a $12 \%$ NuPAGE Bis-Tris gel (Invitrogen). After transfer to Hybond-ECL nitrocellulose (GE Healthcare) the membranes were blocked and incubated with rabbit anti-human RAN (Abcam) (1:500) with 5\% (w/v) fat-free milk powder in PBS containing $0.5 \%$ Tween-20, or mouse anti-human GAPDH (1:3000) overnight at $4{ }^{\circ} \mathrm{C}$. Secondary antibodies were added after washing and bound antibody was detected using enhanced chemiluminescence (ECL).

\subsection{Flow cytometer analysis}

Stable GFP overexpressing DLKP-A cells were trypsinised from 24 -well plates and resuspended at $<500$ cells/ $\mu$ l. The benchtop cytometer (Guava Technologies) was set up using GFP-negative DKLP-A cells to adjust the flow rate and gate the negative population (green fluorescence $<10$ with PMT gain at $600 \mathrm{~V}$ ). GFP-transfected cells were then analysed and the intensity of fluorescence was captured for 5000 cells per sample.

\section{Results}

\subsection{MiR-29a is down-regulated in invasive cancer cells}

An initial bioarray-based study in our laboratory comparing microRNA expression in non- and highly invasive variants of the lung cancer cell line DLKP identified several differentially expressed miRNAs, one of which was miR-29a. Subsequent measurement by qRT-PCR confirmed that miR-29a expression in the invasive variant was less than $45 \%$ of that in the non-invasive cell line (Fig. 1).

\subsection{MiR-29a decreases the invasive phenotype of cancer cells in vitro}

Though ectopic expression of miR-29a has previously been shown to reduce the growth of lung cancer cells in vitro and their tumourigenic potential in vivo, ${ }^{4}$ we were interested to see if it would impact on the invasiveness of DLKP-A cells. The cells were transfected with a short, artificial miR-29a mimic (pre-miR) and seeded on ECM (Matrigel ${ }^{\mathrm{TM}}$ ) $72 \mathrm{~h}$ later in a

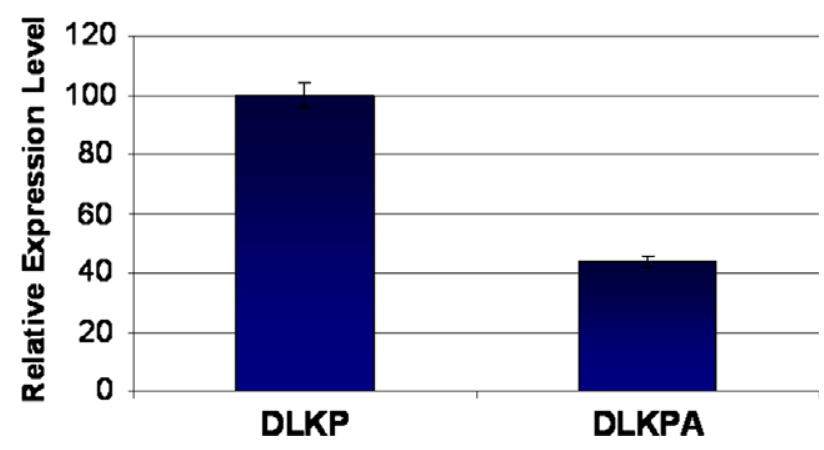

Fig. 1 - Endogenous miR-29a expression levels in DLKP compared to DLKP-A. The samples were normalised using RNU6B expression $(n=3)$. 
A

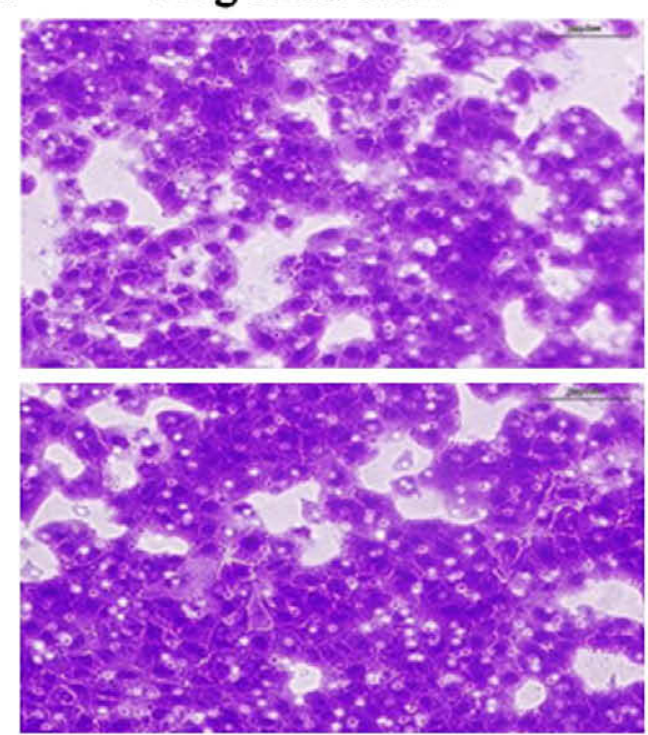

Anti-miR-29a
Neg Pre-miR

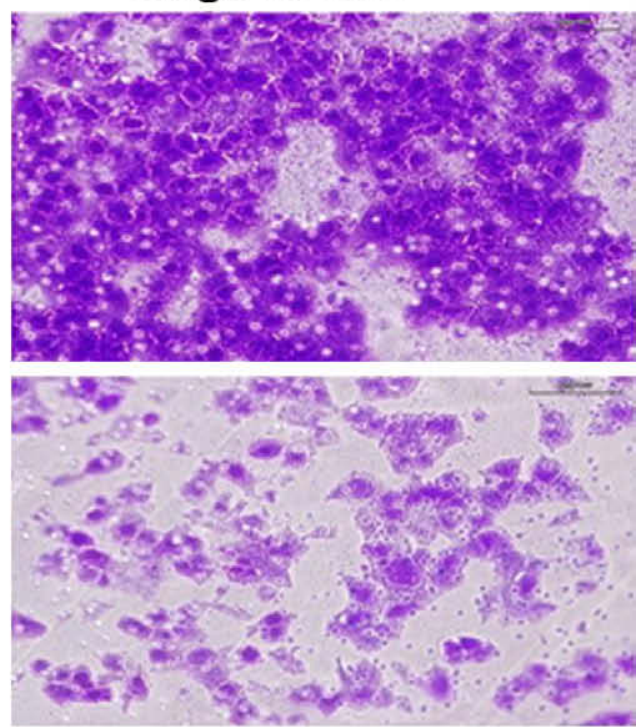

Pre-miR-29a

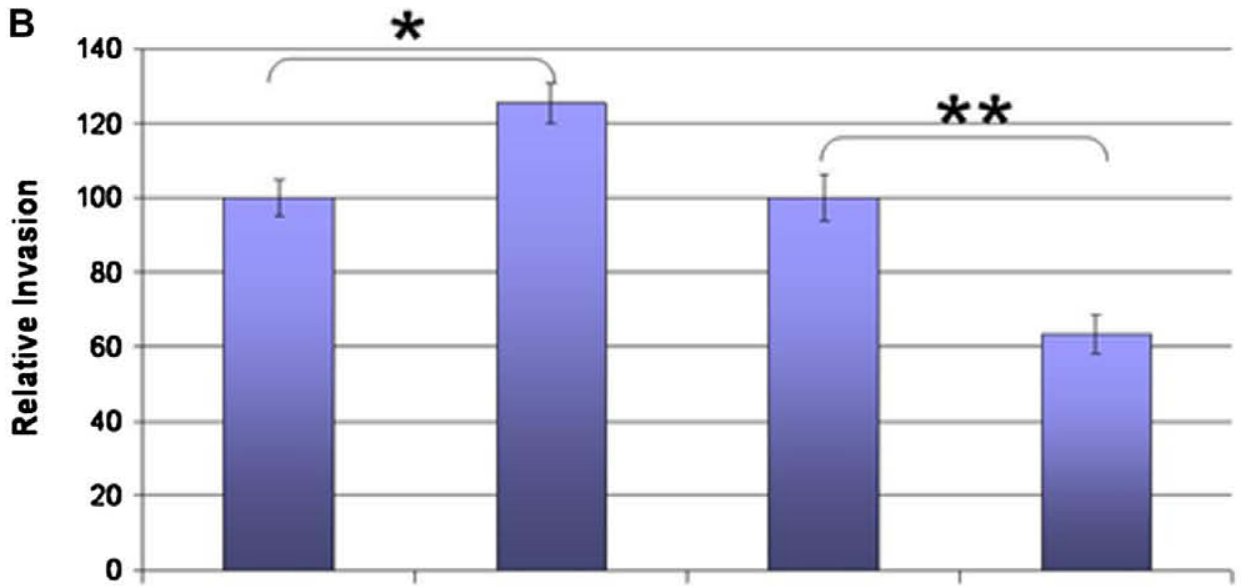

Neg Anti-miR Anti-miR-29a Neg Pre-miR Pre-miR-29a

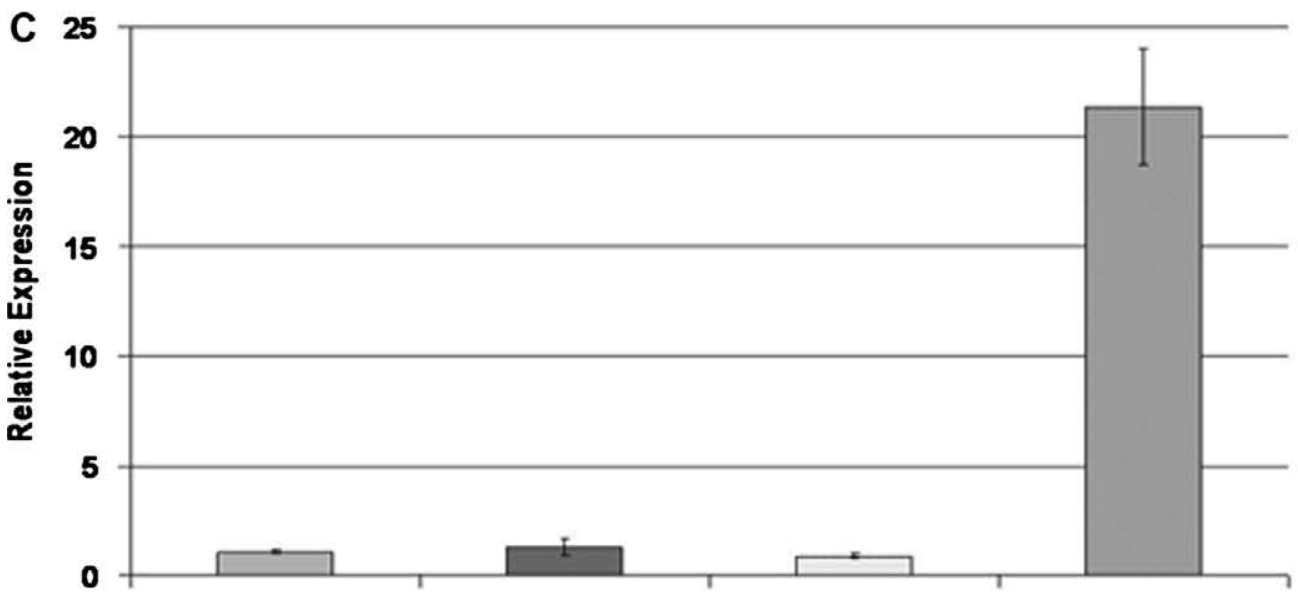

Neg Anti-miR Anti-miR-29a Neg Pre-miR Pre-miR-29a

Fig. 2 - Effect of miR-29a disregulation on invasion in DLKP-A cells. (A) Representative field of view of in vitro invasion inserts at 20 $\times$ magnification. (B) Quantification of relative numbers of invading cells representing average counts from 10 fields-ofview per 2 inserts per sample \pm SD, ${ }^{*} p<0.0005,{ }^{* *} p<10^{-4}$. qRT-PCR to detect relative miR-29a levels in control (neg), anti- and pre-miR-29a-transfected cells (C). 
Boyden chamber in vitro invasion assay. Compared to cells transfected with a non-specific pre-miR control sequence, we observed a $35-40 \%$ reduction in invading cells $24 \mathrm{~h}$ later (Fig. 2a and b). The reciprocal experiment where endogenous miR-29a activity was inhibited by transient transfection with a complementary single-stranded RNA molecule (anti-mir) increased the invasiveness of DLKP-A cells compared to the control, though the effect was less pronounced possibly due to the already highly invasive phenotype of these cells. To confirm that the transfections resulted in the desired impact on cellular levels of miR-29a, qRT-PCR was performed on extracted total RNA. Though the pre-miR treatment increased the detected miR-29a by greater than 20 -fold, we were unable to detect any change in target levels subsequent to anti-miR transfection (Fig. 2c). This is most likely due to the fact that these molecules merely act as inhibitors by competitively binding the target (mature miR-29a) but do not induce degradation, as in the case of siRNA action.

The impact of exogenous upregulation of miR-29a in DLKPA cells led us to question whether the effect would prove to be tissue-type specific or more general. The highly invasive human pancreatic carcinoma cell line, PANC-1, was transfected with pre-miR and similarly displayed a 50\% reduction in its capacity to invade through the matrix (Fig. 3a and b). Quantitative PCR suggested upregulation of $m i R-29 a$ in these cells compared to the negative control (Fig. 3c) though not to the same extent achieved in the DLKP-A cell line.
Further confirmation of its impact on the invasiveness was demonstrated in stable DLKP-A clones that constitutively overexpressed miR-29a. These were generated by cloning a $\sim 250$ bp genomic fragment from DLKP-derived DNA, that included the full miR-29a sequence and flanking sequence, into an expression vector. Stable clones were found to express mature miR-29a at varying levels (Fig. 4b). The invasiveness of a sub set of these clones was measured and found to correlate negatively with expression of miR-29a (Fig. 4a). It was also found that the proliferation of these stable clones was reduced compared to control cells (Fig. 4c); this was not observed in the transient transfections.

\subsection{Proteomic profiling of cells overexpressing miR-29a}

A small number of gene targets of $m i R-29 a$ activity in vitro or in vivo have been verified experimentally in several recent publications. These include $\mathrm{Tcl} 1{ }^{7}$ the DNA methyltransferase enzymes, DNMT3A and $\mathrm{B},{ }^{4} \mathrm{Mcl}-1,{ }^{3} \mathrm{ColA} 1,{ }^{12}$ tristetrapro$\operatorname{lin}^{13}$ and CDC42. ${ }^{14}$ In addition, depending on which software algorithm is employed, several hundred more downstream targets can be in silico predicted. To gain a better understanding of the range of proteins affected either directly or indirectly by this miRNA in vitro, we applied 2D DIGE analysis of lysates from DLKP-A cells transfected transiently with exogenous pre- and anti-miR-29a compared to cells treated with the appropriate non-specific, negative controls. As
A

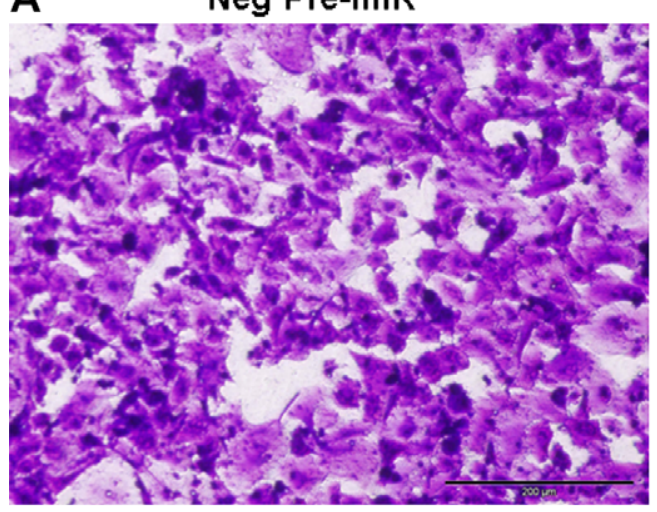

Pre-miR-29a

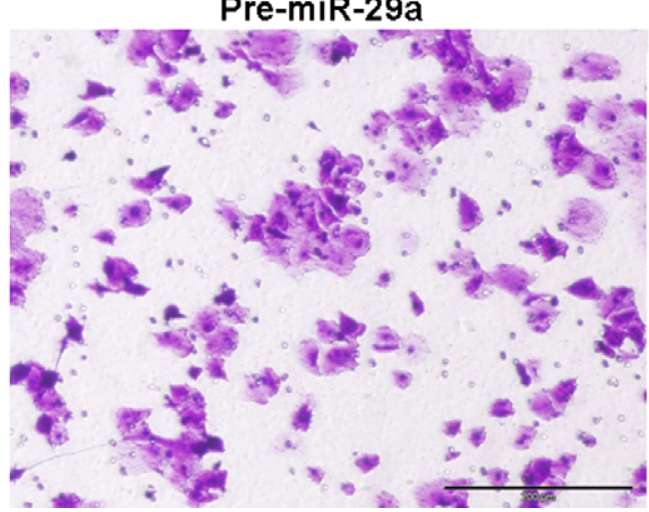

B

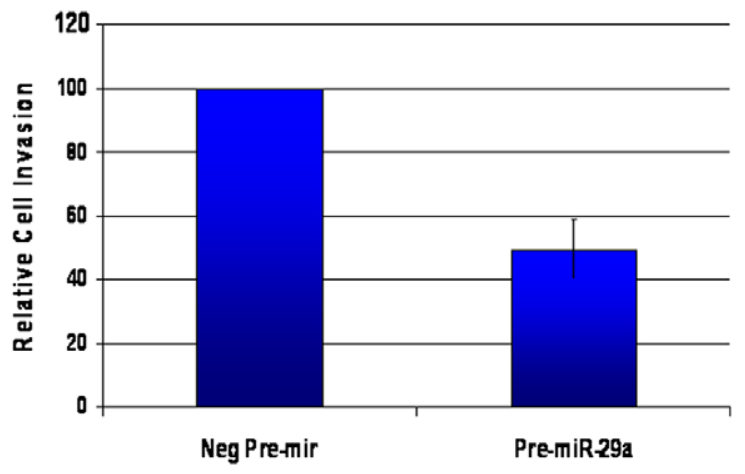

C

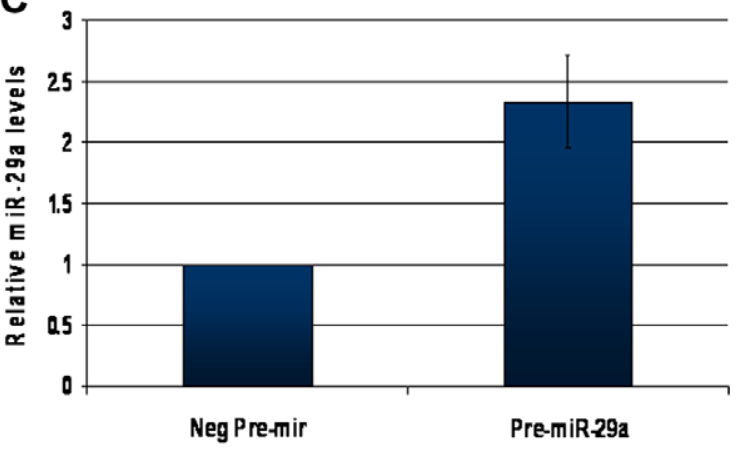

Fig. 3 - Effect of miR-29a upregulation on invasion in PANC-1 cells. (A) Representative field of view of in vitro invasion inserts under 20× magnification. (B) Quantification of relative numbers of invading cells representing average counts from 10 fields of view in 2 Boyden chambers (error bar represents $\pm S E, p<0.02$ ). (C) qRT-PCR to detect relative miR-29a levels in control and premiR-29a-transfected cells ( $n=2, p=0.13$, error bars \pm SE). 
A

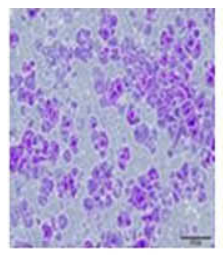

Neg-Mir

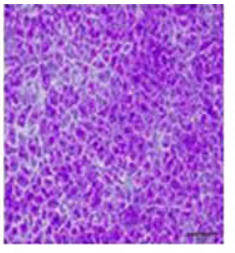

miR-29a-1

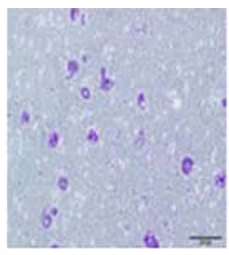

miR-29a-3

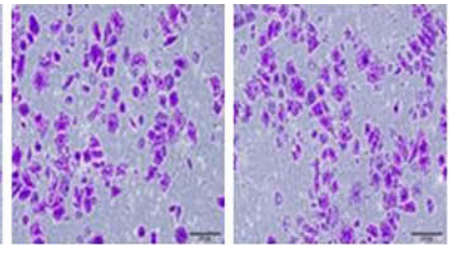

miR-29a-4 miR-29a-11

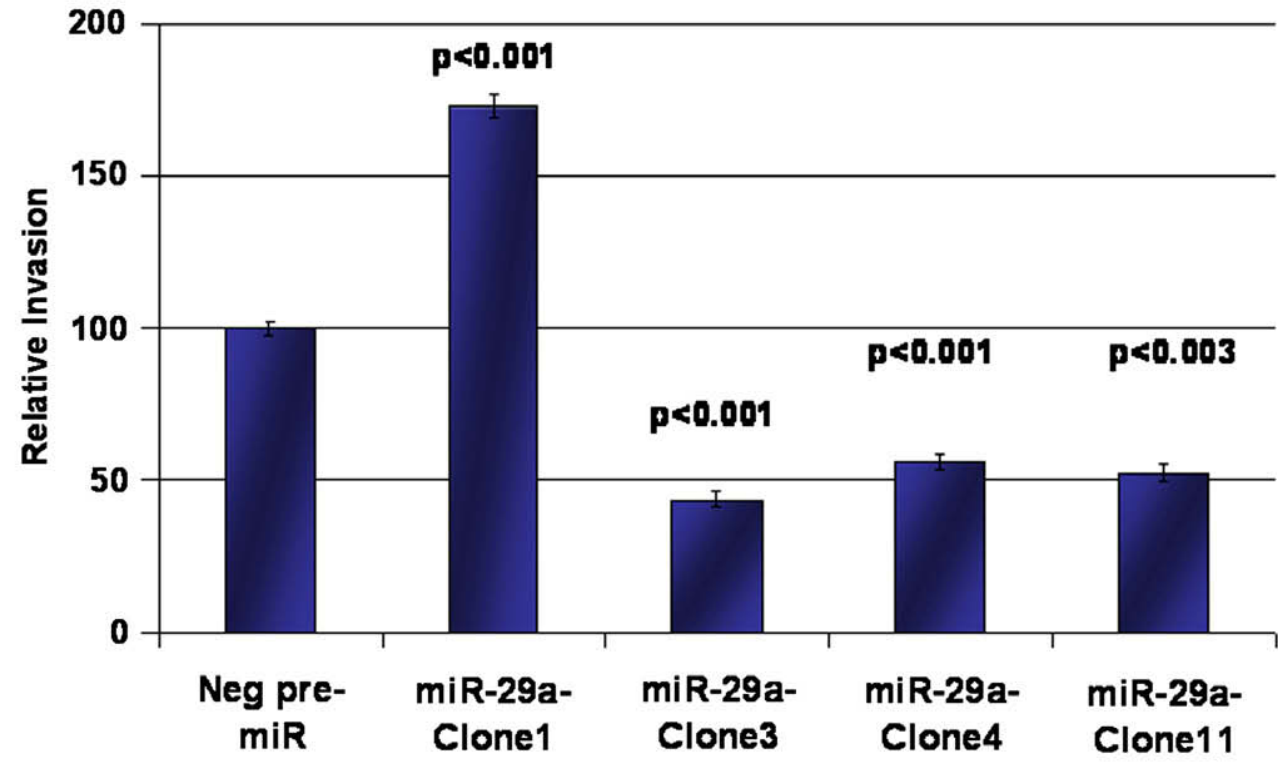

B

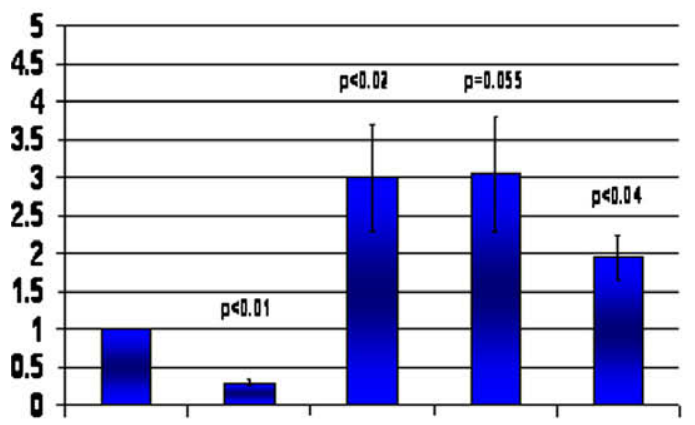

Neg Pre- Mir-29a- Mir-20a. Mir-29a. Mir-29a.
C

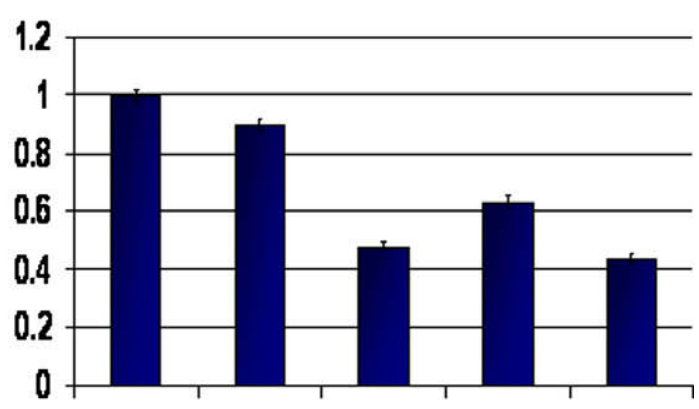

Neg Pre- miR-29a- miR-29a- miR-29a- miR.29amiR Clone1 Clone3 Clonet Clone11

Fig. 4 - Invasive phenotype of DLKP-A clones stably transfected with miR-29a or Neg-mir expression vector. (A) Relative invasion of each of the clones compared to a negative-mir clone. Neg-Mir represents a clone derived from cells stably transfected with the expression vector incorporating a non-specific sequence of similar length to the mir-29a insert ( $n=3$, error bars \pm SE). (B) Relative expression of miR-29a in stable clones $(n=3$, error bars \pm SE). (C) Cell proliferation of the 5 clones relative to Neg Pre-mir, $(p<0.001$ in all samples, error bars $\pm \mathrm{SE})$.

expected, the protein spots were observed in both treatments that were both increased and decreased compared to the control-transfected cells. To simplify the subsequent analysis we focused on the proteins that were down-regulated in response to pre-miR treatment and up-regulated in anti-miR-treated cells. These comprised the primary list of 75 potentially 'direct' targets of miR-29a activity (Table 1). The proteins with the opposite trend in expression, i.e. upregulated upon treatment with pre-miR-29a or down-regulated upon treatment with anti-miR-29a, would be expected to be indirect, downstream targets of miR-29a action. However, it is likely that some of the proteins on the primary list could also be indirect targets whose expression is affected by the action of a miR-29a target gene. In addition, several proteins were identified at more than one spot location suggesting the presence of post-translational modifications on these molecules.

The range of differential expression of the identified proteins was modest with the greatest change being 1.63-fold down-regulation of macrophage migration inhibitory factor 


\begin{tabular}{|c|c|c|c|c|c|c|c|c|}
\hline Gene symbol & Gene name & Protein ID & $\begin{array}{l}\text { GenBank } \\
\text { ID }\end{array}$ & $\begin{array}{l}\text { Mass } \\
(\mathrm{Da})\end{array}$ & $\begin{array}{l}\text { Fold } \\
\text { change }\end{array}$ & ANOVA & $\begin{array}{c}\text { Predicted } \\
\text { target of } \\
\text { miR-29a }\end{array}$ & $\begin{array}{l}\text { Biological } \\
\text { process }\end{array}$ \\
\hline HIST4H4* & Histone $\mathrm{H} 4$ & gil75061938| & NM_175054 & 11,360 & -1.64 & 0.034 & & $\begin{array}{l}\text { Chromatin } \\
\text { packaging and } \\
\text { remodelling }\end{array}$ \\
\hline MIF & $\begin{array}{l}\text { Macrophage migration } \\
\text { inhibitory factor }\end{array}$ & gil1170955| & NM_002415 & 12,468 & -1.63 & 0.035 & & $\begin{array}{l}\text { Macrophage- } \\
\text { mediated } \\
\text { immunity }\end{array}$ \\
\hline ISG15 & $\begin{array}{l}\text { ISG15 ubiquitin-like } \\
\text { modifier }\end{array}$ & gil386837| & NM_005101 & 17,910 & -1.63 & 0.0026 & & Proteolysis \\
\hline PRDX1* & Peroxiredoxin 1 & gil548453| & NM_002574 & 22,096 & -1.53 & 0.035 & & $\begin{array}{l}\text { Antioxidation } \\
\text { and free radical } \\
\text { removal }\end{array}$ \\
\hline CFL1 & Cofilin-1 & gil116848| & NM_005507 & 18,491 & -1.53 & 0.0019 & & Apoptosis \\
\hline PEBP1 & $\begin{array}{l}\text { Phosphatidylethanolamine- } \\
\text { binding protein } 1\end{array}$ & gil1352726l & NM_002567 & 21,044 & -1.53 & 0.0004 & $\mathrm{x}$ & $\begin{array}{l}\text { Other signal } \\
\text { transduction }\end{array}$ \\
\hline HIST4H4* & Histone $\mathrm{H} 4$ & gil75061938| & NM_175054 & 11,360 & -1.46 & 0.0011 & & $\begin{array}{l}\text { Chromatin } \\
\text { packaging and } \\
\text { remodelling }\end{array}$ \\
\hline LGALS1 & $\begin{array}{l}\text { Histidine triad nucleotide- } \\
\text { binding protein } 1\end{array}$ & gil42542978| & NM_002305 & 14,910 & -1.45 & 0.0005 & & $\begin{array}{l}\text { Cell adhesion; } \\
\text { other immune } \\
\text { and defence; } \\
\text { induction of } \\
\text { apoptosis }\end{array}$ \\
\hline RPL11 & 60S ribosomal protein L11 & gil51701767| & NM_000975 & 20,240 & -1.45 & 0.0005 & & $\begin{array}{l}\text { Protein } \\
\text { biosynthesis }\end{array}$ \\
\hline RPS12 & 40 S ribosomal protein S12 & gil133742| & NM_001016 & 14,517 & -1.43 & 0.012 & & $\begin{array}{l}\text { Protein } \\
\text { biosynthesis }\end{array}$ \\
\hline GMFB & $\begin{array}{l}\text { Glia maturation } \\
\text { factor beta }\end{array}$ & gil46577593| & NM_004124 & 16,703 & -1.43 & 0.0021 & $\mathrm{x}$ & Neurogenesis \\
\hline BTF3L4 & $\begin{array}{l}\text { Transcription factor BTF3 } \\
\text { homologue } 4\end{array}$ & gil75042131l & NM_152265 & 17,260 & -1.43 & 0.0019 & & Unclassified \\
\hline CLPP & $\begin{array}{l}\text { ATP-dependent Clp protease } \\
\text { proteolytic subunit }\end{array}$ & gil3023512| & NM_006012 & 30,161 & -1.42 & 0.03 & & Proteolysis \\
\hline FABP5 & $\begin{array}{l}\text { Fatty acid-binding protein, } \\
\text { epidermal }\end{array}$ & gil232081l & NM_001444 & 15,155 & -1.42 & 0.005 & & $\begin{array}{l}\text { Lipid and fatty } \\
\text { acid transport }\end{array}$ \\
\hline $\mathrm{HIBCH}$ & $\begin{array}{l}\text { 3-Hydroxyisobutyryl-CoA } \\
\text { hydrolase }\end{array}$ & gil146324905| & NM_014362 & 43,454 & -1.42 & 0.005 & & $\begin{array}{l}\text { Carbohydrate } \\
\text { metabolism } \\
\text { and fatty acid } \\
\text { beta-oxidation }\end{array}$ \\
\hline PPIB & Cyclosporin & gil1310882| & NM_000942 & 19,700 & -1.41 & 0.027 & $\mathrm{x}$ & $\begin{array}{l}\text { Protein folding; } \\
\text { nuclear } \\
\text { transport; } \\
\text { immunity and } \\
\text { defence }\end{array}$ \\
\hline PSMB4 & $\begin{array}{l}\text { Proteasome subunit beta } \\
\text { type- } 4 \text { precursor }\end{array}$ & gil116242733| & NM_002796 & 29,186 & -1.41 & 0.0024 & & Proteolysis \\
\hline PPIA* & $\begin{array}{l}\text { Peptidylprolyl isomerase A } \\
\text { (cyclophilin A) }\end{array}$ & gil75766275| & NM_021130 & 18,030 & -1.4 & 0.0045 & $\mathrm{x}$ & $\begin{array}{l}\text { Protein folding; } \\
\text { nuclear } \\
\text { transport; } \\
\text { immunity and } \\
\text { defence }\end{array}$ \\
\hline SOD1 & Superoxide dismutase & gil134611l & NM_000454 & 15,926 & -1.39 & 0.043 & & $\begin{array}{l}\text { Immunity and } \\
\text { defence }\end{array}$ \\
\hline
\end{tabular}


Table 1 - (continued)

\begin{tabular}{|c|c|c|c|c|c|c|c|c|}
\hline Gene symbol & Gene name & Protein ID & $\begin{array}{l}\text { GenBank } \\
\text { ID }\end{array}$ & $\begin{array}{l}\text { Mass } \\
(\mathrm{Da})\end{array}$ & $\begin{array}{l}\text { Fold } \\
\text { change }\end{array}$ & ANOVA & $\begin{array}{c}\text { Predicted } \\
\text { target of } \\
\text { miR-29a }\end{array}$ & $\begin{array}{l}\text { Biological } \\
\text { process }\end{array}$ \\
\hline GSTK1 & $\begin{array}{l}\text { Glutathione S-transferase } \\
\text { kappa } 1\end{array}$ & gil12643338| & NM_015917 & 25,480 & -1.39 & 0.0015 & & $\begin{array}{l}\text { Translational } \\
\text { regulation }\end{array}$ \\
\hline PPIA* & $\begin{array}{l}\text { Peptidylprolyl isomerase A } \\
\text { (cyclophilin A) }\end{array}$ & gil3659980l & NM_021130 & 18,090 & -1.36 & 0.02 & $\mathrm{x}$ & $\begin{array}{l}\text { Protein folding; } \\
\text { nuclear transport; } \\
\text { immunity and } \\
\text { defence }\end{array}$ \\
\hline TPx-B & Thioredoxin Peroxidase B & gil9955016l & NM_005809 & 21,680 & -1.36 & 0.0011 & & Unknown \\
\hline APRT & $\begin{array}{l}\text { Adenine } \\
\text { phosphoribosyltransferase }\end{array}$ & gil114074| & NM_000485 & 19,595 & -1.35 & 0.015 & & Unclassified \\
\hline PPIA* & $\begin{array}{l}\text { Peptidylprolyl isomerase A } \\
\text { (cyclophilin A) }\end{array}$ & gil75766275| & NM_021130 & 18,030 & -1.35 & 0.0091 & $\mathrm{x}$ & Unknown \\
\hline IGH2bM35a & $\begin{array}{l}\text { Immunoglobulin heavy } \\
\text { chain }\end{array}$ & gil7161037| & AJ253041 & 10,600 & -1.35 & 0.004 & & Unknown \\
\hline RAN & RAS-related nuclear protein & gil5107684l & NM_006325 & 23,300 & -1.35 & 0.00024 & & $\begin{array}{l}\text { RNA localisation; } \\
\text { intracellular } \\
\text { signalling } \\
\text { cascade; nuclear } \\
\text { transport and cell } \\
\text { cycle }\end{array}$ \\
\hline ATP6V1E1 & $\begin{array}{l}\text { Vacuolar ATP synthase } \\
\text { subunit E } 1\end{array}$ & gil549207l & NM_001696 & 26,129 & -1.34 & 0.013 & & $\begin{array}{l}\text { Nucleoside, } \\
\text { nucleotide and } \\
\text { nucleic acid } \\
\text { metabolism }\end{array}$ \\
\hline PRDX1* & Peroxiredoxin 1 & gil548453| & NM_002574 & 22,096 & -1.34 & 0.0035 & & $\begin{array}{l}\text { Antioxidation and } \\
\text { free radical } \\
\text { removal }\end{array}$ \\
\hline HINT1 & $\begin{array}{l}\text { Histidine triad nucleotide- } \\
\text { binding protein } 1\end{array}$ & gil1708543| & NM_005340 & 13,793 & -1.33 & 0.0048 & & Unclassified \\
\hline GNB2L1 & $\begin{array}{l}\text { Guanine nucleotide-binding } \\
\text { protein subunit beta-2-like } 1\end{array}$ & gil54037164l & NM_006098 & 35,055 & -1.32 & 0.048 & & $\begin{array}{l}\text { Signal } \\
\text { transduction; } \\
\text { protein targeting }\end{array}$ \\
\hline PRDX3 & Peroxiredoxin 3 isoform $b$ & gil32483377| & NM_006793 & 26,110 & -1.32 & 0.0031 & & $\begin{array}{l}\text { Antioxidation and } \\
\text { free radical } \\
\text { removal }\end{array}$ \\
\hline ARL3* & $\begin{array}{l}\text { ADP-ribosylation factor-like } \\
\text { protein } 3\end{array}$ & gil543851 & NM_004311 & 20,443 & -1.31 & 0.046 & $\mathrm{x}$ & $\begin{array}{l}\text { General vesicle } \\
\text { transport }\end{array}$ \\
\hline PRDX1* & Peroxiredoxin 1 & gil55959887| & NM_002574 & 19,130 & -1.31 & 0.019 & & $\begin{array}{l}\text { Antioxidation and } \\
\text { free radical } \\
\text { removal }\end{array}$ \\
\hline PPIA* & $\begin{array}{l}\text { Peptidylprolyl isomerase A } \\
\text { (cyclophilin A) }\end{array}$ & gil2981764| & NM_021130 & 18,090 & -1.31 & 0.0069 & $\mathrm{x}$ & Unknown \\
\hline SFRS1 & $\begin{array}{l}\text { Splicing factor, arginine/ } \\
\text { serine-rich } 1\end{array}$ & gil45708738| & NM_006924 & 22,560 & -1.29 & 0.042 & & mRNA splicing \\
\hline ERP29 & $\begin{array}{l}\text { Endoplasmic reticulum } \\
\text { protein ERp29 precursor }\end{array}$ & gil6015110l & NM_006817 & 28,975 & -1.29 & 0.0027 & & $\begin{array}{l}\text { Constitutive } \\
\text { exocytosis }\end{array}$ \\
\hline CMPK1 & $\begin{array}{l}\text { Cytidine monophosphate } \\
\text { kinase }\end{array}$ & gil12644008| & NM_016308 & 22,208 & -1.29 & 0.00039 & $\mathrm{x}$ & $\begin{array}{l}\text { Pyrimidine } \\
\text { metabolism }\end{array}$ \\
\hline C20orf45 & $\begin{array}{l}\text { Chromosome } 20 \text { open } \\
\text { reading frame } 45\end{array}$ & gil26392626l & NM_016045 & 21,481 & -1.28 & 0.019 & & Unclassified \\
\hline PSMA2* & $\begin{array}{l}\text { Proteasome subunit alpha } \\
\text { type- } 6\end{array}$ & gil46397655| & NM_002791 & 27,382 & -1.28 & 0.017 & & Proteolysis \\
\hline NDKA & $\begin{array}{l}\text { Nucleoside diphosphate } \\
\text { kinase A }\end{array}$ & gil127981| & NM_198175 & 17,138 & -1.28 & 8.40E-05 & & $\begin{array}{l}\text { Pyrimidine } \\
\text { metabolism }\end{array}$ \\
\hline VBP1 & VHL-binding protein-1 & gil1465751l & NM_003372 & 19,520 & -1.27 & 0.015 & & $\begin{array}{l}\text { Protein folding } \\
\text { and protein } \\
\text { complex } \\
\text { assembly }\end{array}$ \\
\hline HPRT & $\begin{array}{l}\text { Hypoxanthine } \\
\text { phosphoribosyltransferase }\end{array}$ & gil459815| & NM_000194 & 24,730 & -1.27 & 0.0046 & & $\begin{array}{l}\text { Purine } \\
\text { metabolism }\end{array}$ \\
\hline THOC6 & $\begin{array}{l}\text { THO complex subunit } 6 \\
\text { homologue }\end{array}$ & gil74759455| & NM_024339 & 37,511 & -1.26 & 0.023 & & Unclassified \\
\hline
\end{tabular}




\section{Table 1 - (continued)}

\begin{tabular}{|c|c|c|c|c|c|c|c|c|}
\hline Gene symbol & Gene name & Protein ID & $\begin{array}{l}\text { GenBank } \\
\text { ID }\end{array}$ & $\begin{array}{l}\text { Mass } \\
(\mathrm{Da})\end{array}$ & $\begin{array}{l}\text { Fold } \\
\text { change }\end{array}$ & ANOVA & $\begin{array}{l}\text { Predicted } \\
\text { target of } \\
\text { miR-29a }\end{array}$ & $\begin{array}{l}\text { Biological } \\
\text { process }\end{array}$ \\
\hline PRDX1* & Peroxiredoxin 1 & gil55959887| & NM_002574 & 19,130 & -1.26 & 0.015 & & $\begin{array}{l}\text { Antioxidation and } \\
\text { free radical } \\
\text { removal }\end{array}$ \\
\hline Sfrs3 & $\begin{array}{l}\text { Splicing factor, } \\
\text { arginine/serine-rich } 3\end{array}$ & gil51338673| & NM_003017 & 19,318 & -1.26 & 0.011 & & mRNA splicing \\
\hline CFL1 & Cofilin-1 & gil116848| & NM_005507 & 18,491 & -1.26 & 0.0024 & & Cell structure \\
\hline PARK7 & $\begin{array}{l}\text { Parkinson disease } \\
\text { (autosomal recessive, } \\
\text { early onset) } 7\end{array}$ & gil42543006| & NM_007262 & 20,060 & -1.26 & 0.00072 & & $\begin{array}{l}\text { Cell proliferation } \\
\text { and differentiation }\end{array}$ \\
\hline GNB3 & $\begin{array}{l}\text { Guanine nucleotide- } \\
\text { binding protein } \\
\text { subunit beta-3 }\end{array}$ & gil121011l & NM_002075 & 37,197 & -1.25 & 0.048 & & $\begin{array}{l}\text { G-protein mediated } \\
\text { signalling }\end{array}$ \\
\hline GRB2 & $\begin{array}{l}\text { Growth factor } \\
\text { receptor-bound } \\
\text { protein } 2\end{array}$ & gil28876| & NM_002086 & 18,620 & -1.25 & 0.0059 & & $\begin{array}{l}\text { Receptor protein } \\
\text { tyrosine kinase } \\
\text { signalling pathway }\end{array}$ \\
\hline ESD & $\begin{array}{l}\text { Esterase D/ } \\
\text { formylglutathione } \\
\text { hydrolase }\end{array}$ & gil12654663| & NM_001984 & 32,020 & -1.25 & 0.0013 & & Unclassified \\
\hline NDUFA10 & $\begin{array}{l}\text { NADH } \\
\text { dehydrogenase } \\
\text { (ubiquinone) } 1 \text { alpha } \\
\text { subcomplex }\end{array}$ & gil13097333| & NM_004544 & 41,070 & -1.25 & 0.0013 & & $\begin{array}{l}\text { Oxidative } \\
\text { phosphorylation }\end{array}$ \\
\hline LYPLA2 & Lysophospholipase II & gil41017276| & NM_007260 & 24,721 & -1.25 & 0.0003 & & $\begin{array}{l}\text { Lipid metabolism; } \\
\text { cell proliferation } \\
\text { and differentiation }\end{array}$ \\
\hline PRDX1* & Peroxiredoxin 1 & gil55959887| & NM_002574 & 19,130 & -1.24 & 0.037 & & $\begin{array}{l}\text { Antioxidation and } \\
\text { free radical } \\
\text { removal }\end{array}$ \\
\hline FKBP3 & $\begin{array}{l}\text { FK506-binding } \\
\text { protein } 3\end{array}$ & gil232096| & NM_002013 & 25,161 & -1.24 & 0.03 & & $\begin{array}{l}\text { Protein folding and } \\
\text { cell cycle control }\end{array}$ \\
\hline HSPB1 & $\begin{array}{l}\text { Heat shock protein } \\
\text { beta-1 }\end{array}$ & gil19855073| & NM_001540 & 22,769 & -1.24 & 0.03 & & $\begin{array}{l}\text { Protein folding and } \\
\text { stress response }\end{array}$ \\
\hline CYC & Cytochrome c & gil42560195| & NM_018947 & 11,741 & -1.24 & 0.018 & $\mathrm{x}$ & $\begin{array}{l}\text { Oxidative } \\
\text { phosphorylation; } \\
\text { apoptotic processes }\end{array}$ \\
\hline ANXA1 & Annexin A1 & gil113944| & NM_000700 & 38,690 & -1.24 & 0.006 & & $\begin{array}{l}\text { Fatty acid } \\
\text { metabolism; } \\
\text { receptor-mediated } \\
\text { signal transduction } \\
\text { and cell motility }\end{array}$ \\
\hline PSMA2* & $\begin{array}{l}\text { Proteasome subunit } \\
\text { alpha type- } 2\end{array}$ & gil39644890l & NM_002787 & 24,970 & -1.23 & 0.0096 & & Proteolysis \\
\hline PRDX6 & Peroxiredoxin-6 & gil1718024| & NM_004905 & 25,019 & -1.22 & 0.041 & $\mathrm{x}$ & $\begin{array}{l}\text { Antioxidation and } \\
\text { free radical } \\
\text { removal }\end{array}$ \\
\hline PGAM1 & $\begin{array}{l}\text { Phosphoglycerate } \\
\text { Mutase }\end{array}$ & gil67464305l & NM_002629 & 29,970 & -1.22 & 0.0021 & & Glycolysis \\
\hline GALE & $\begin{array}{l}\text { UDP-galactose-4- } \\
\text { epimerase }\end{array}$ & gil68056598| & NM_001008216 & 38,257 & -1.21 & 0.037 & & $\begin{array}{l}\text { Carbohydrate } \\
\text { metabolism }\end{array}$ \\
\hline PSMB2 & $\begin{array}{l}\text { Proteasome subunit } \\
\text { beta type- } 2\end{array}$ & gil1709762| & NM_002794 & 22,822 & -1.21 & 0.029 & $\mathrm{x}$ & Proteolysis \\
\hline ANXA2 & Annexin A2 & gil56967119| & NM_001002858 & 36,640 & -1.21 & 0.0059 & $\mathrm{x}$ & $\begin{array}{l}\text { Intracellular } \\
\text { protein traffic; } \\
\text { Mesoderm } \\
\text { development; Cell } \\
\text { structure and } \\
\text { motility }\end{array}$ \\
\hline PAFAH1B2 & $\begin{array}{l}\text { Platelet-activating } \\
\text { factor } \\
\text { acetylhydrolase IB } \\
\text { subunit beta }\end{array}$ & gil55977293| & NM_002572 & 25,553 & -1.21 & 0.0043 & & Unclassified \\
\hline
\end{tabular}


Table 1 - (continued)

\begin{tabular}{|c|c|c|c|c|c|c|c|c|}
\hline Gene symbol & Gene name & Protein ID & $\begin{array}{l}\text { GenBank } \\
\text { ID }\end{array}$ & $\begin{array}{l}\text { Mass } \\
(\mathrm{Da})\end{array}$ & $\begin{array}{l}\text { Fold } \\
\text { change }\end{array}$ & ANOVA & $\begin{array}{c}\text { Predicted } \\
\text { target of } \\
\text { miR-29a }\end{array}$ & $\begin{array}{l}\text { Biological } \\
\text { process }\end{array}$ \\
\hline CACYBP & $\begin{array}{l}\text { Calcyclin-binding } \\
\text { protein }\end{array}$ & gil46576651l & NM_014412 & 26,194 & -1.2 & 0.036 & & Proteolysis \\
\hline HIBADH & $\begin{array}{l}\text { 3-Hydroxyisobutyrate } \\
\text { dehydrogenase }\end{array}$ & gil12643395| & NM_152740 & 35,306 & -1.2 & 0.0074 & & $\begin{array}{l}\text { Amino acid } \\
\text { biosynthesis and } \\
\text { amino acid } \\
\text { catabolism }\end{array}$ \\
\hline IGv & $\begin{array}{l}\text { Immunoglobulin } \\
\text { heavy chain subgroup } \\
\text { VIII V-D-J region }\end{array}$ & gil348186| & & 13,830 & -1.2 & 0.0036 & & Unclassified \\
\hline KIAA1598 & $\begin{array}{l}\text { Formin-like } \\
\text { (pthr23213:sf23) }\end{array}$ & gil156637366| & NM_018330 & 71596 & 1.21 & 0.034 & & Cell motility \\
\hline RuvB-like 2 & $\begin{array}{l}48 \mathrm{kDa} \text { TATA box- } \\
\text { binding protein- } \\
\text { interacting } \\
\text { protein }\end{array}$ & gil28201890l & NM_006666 & 51125 & 1.22 & 0.049 & & $\begin{array}{l}\text { mRNA } \\
\text { transcription } \\
\text { regulation; } \\
\text { Embryogenesis; } \\
\text { Mesoderm } \\
\text { development }\end{array}$ \\
\hline ACTC1 & Alpha-actin-1 & gil55976646| & NM_005159 & 42024 & 1.22 & 0.036 & $\mathrm{X}$ & $\begin{array}{l}\text { Exocytosis; } \\
\text { Endocytosis; } \\
\text { Transport; } \\
\text { Cytokinesis; } \\
\text { Cell structure }\end{array}$ \\
\hline ATP5A1 & $\begin{array}{l}\text { ATP synthase subunit } \\
\text { alpha, mitochondrial } \\
\text { precursor }\end{array}$ & gil158514235| & NM_001001937 & 59714 & 1.22 & 0.013 & & UnClassified \\
\hline EEF1A1 & $\begin{array}{l}\text { Eukaryotic } \\
\text { translation } \\
\text { elongation factor } 1 \\
\text { alpha } 1\end{array}$ & gil31092| & NM_001402 & 50450 & 1.23 & 0.022 & & $\begin{array}{l}\text { Translational } \\
\text { regulation }\end{array}$ \\
\hline ENO1 & Enolase-alpha & gil31873302| & NM_001428 & 47420 & 1.24 & 0.055 & & Glycolysis \\
\hline PGK1 & $\begin{array}{l}\text { Phosphoglycerate } \\
\text { kinase } 1\end{array}$ & gil48145549| & NM_000291 & 44980 & 1.24 & 0.036 & & Glycolysis \\
\hline CCT3 & $\begin{array}{l}\text { T-complex protein } 1 \\
\text { subunit gamma }\end{array}$ & gil66774185| & NM_005998 & 60495 & 1.24 & 0.024 & & $\begin{array}{l}\text { Protein } \\
\text { folding;Protein } \\
\text { complex assembly }\end{array}$ \\
\hline SERBP1 & $\begin{array}{l}\text { Plasminogen } \\
\text { activator inhibitor } 1 \\
\text { RNA-binding protein }\end{array}$ & gil52783206| & NM_001018067 & 44939 & 1.24 & 0.0036 & & UnClassified \\
\hline EF2 & Elongation factor 2 & gil119172| & NM_001961 & 95277 & 1.25 & 0.051 & & $\begin{array}{l}\text { Protein } \\
\text { biosynthesis }\end{array}$ \\
\hline TRXR1 & $\begin{array}{l}\text { Thioredoxin } \\
\text { reductase } 1\end{array}$ & gil50403780l & NM_003330 & 55490 & 1.25 & 0.02 & & $\begin{array}{l}\text { Electron } \\
\text { transport;Other } \\
\text { metabolism }\end{array}$ \\
\hline LOC652797 & $\begin{array}{l}\text { Pyruvate kinase } \\
\text { isozymes M1/M2 }\end{array}$ & gil20178296| & XM_001719890 & 57900 & 1.27 & 0.024 & & Unknown \\
\hline GRP94 & $\begin{array}{l}\text { Heat shock protein } \\
\text { gp96 precursor }\end{array}$ & gil15010550l & NM_003299 & 90350 & 1.28 & 0.055 & & $\begin{array}{l}\text { Protein } \\
\text { folding;Stress } \\
\text { response }\end{array}$ \\
\hline ALDH1A1 & $\begin{array}{l}\text { Aldehyde } \\
\text { dehydrogenase } 1\end{array}$ & gil2183299| & NM_000689 & 55440 & 1.28 & 0.047 & & $\begin{array}{l}\text { Other carbon } \\
\text { metabolism }\end{array}$ \\
\hline РTBP1 & $\begin{array}{l}\text { Polypyrimidine tract- } \\
\text { binding protein } 1\end{array}$ & gil131528| & NM_002819 & 57186 & 1.29 & 0.0074 & & mRNA splicing \\
\hline DDT & $\begin{array}{l}\text { D-dopachrome } \\
\text { decarboxylase }\end{array}$ & gil2828192| & NM_001355 & 12704 & 1.35 & 0.039 & & $\begin{array}{l}\text { Macrophage- } \\
\text { mediated } \\
\text { immunity }\end{array}$ \\
\hline
\end{tabular}

(MIF) upon pre-miR-29a treatment but more typically in the range 1.2-1.4-fold. In silico analysis of the $3^{\prime}$ UTRs of these genes predicted that only 14 contained potential 'seed' sequences, i.e. at least 6 matches between nt2-8 at the $5^{\prime}$ end of miR-29a. Analysis of the proteins on the primary list to investigate the cellular functions that they have been previously associated with revealed a bias towards proliferation, apoptosis, secretion and motility (Table 1). 

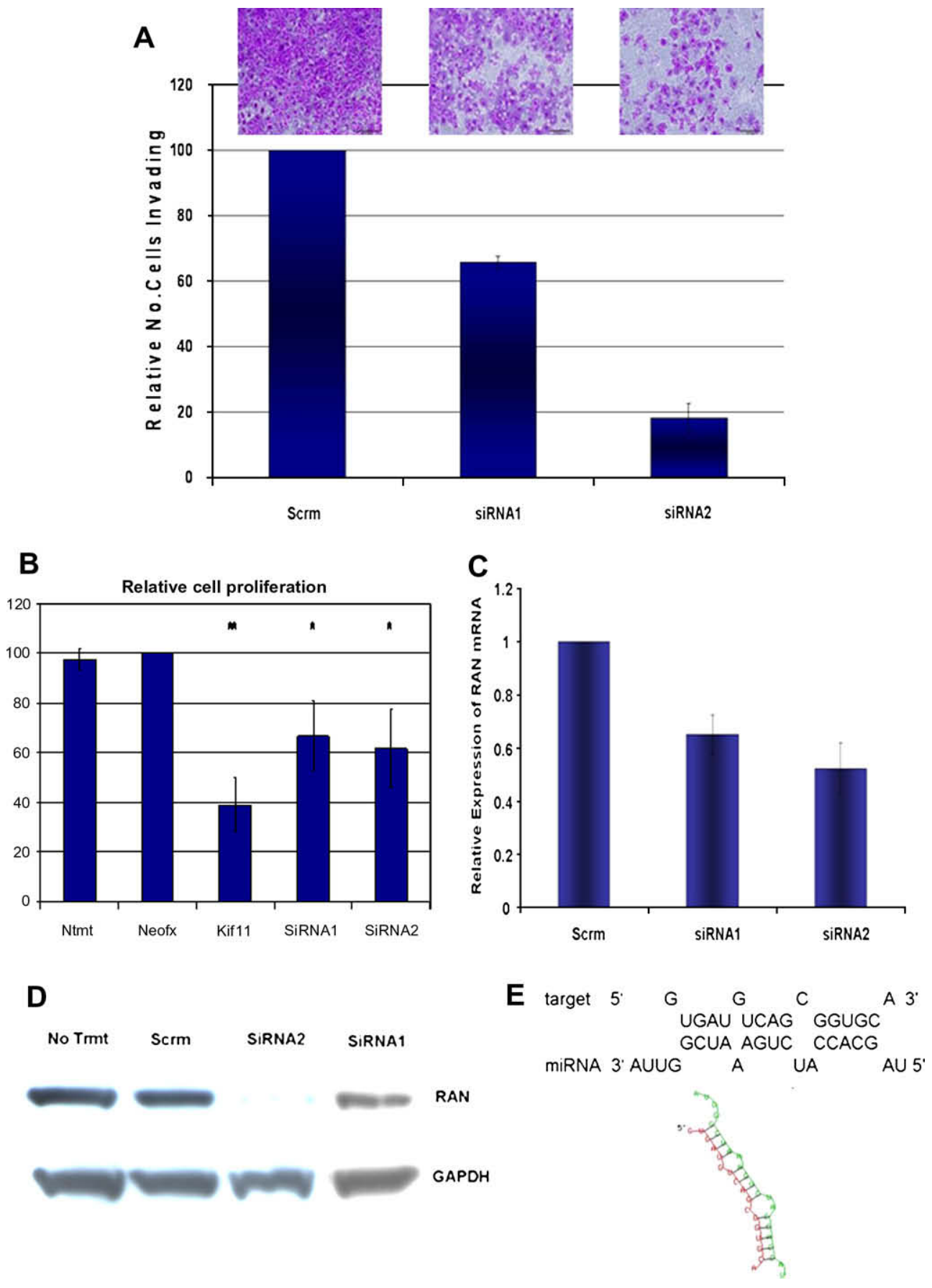

Fig. 5 - Impact of RAN-specific knockdown on DLKP-A cells using 2 independent siRNA sequences. (A) Specific knockdown of RAN by transient transfection of siRNA in DLKP-A reduces in vitro invasion $\left( \pm S D, p<10^{-6}\right)$. (B) proliferation, $\left( \pm S D,{ }^{*} p<0.02\right.$, ${ }^{* *} p<0.0001$ ), Kif11 denotes kinesin positive control. Ntmt $=$ no treatment, Scrm = scrambled control siRNA. (C) Confirmation of siRNA-induced knockdown of RAN mRNA by $q$ PCR $( \pm S E, n=2)$. (D) protein by Western blot. (E) RNA hybrid software-predicted interaction between miR-29a and the RAN 3' UTR.

\subsection{Functional investigation of miR-29 target proteins}

A small panel of the identified proteins was chosen to investigate the impact of knocking down their expression individually in vitro. These targets included Annexin A2 (ANXA2), growth factor receptor-bound 2 (GRB2), macrophage migratory inhibitory factor (MIF) - which had the highest fold change after pre-miR-29a treatment - and Ras-related nuclear protein (RAN). The latter three were chosen based on previous associations with an invasive phenotype or metastatic disease, whereas ANXA2 was picked based on in silico predictions of a miR-29a binding site. Though siRNA-mediated knockdown was verified in all cases by qRT-PCR (data not shown), only RAN depletion impacted on the invasiveness of DLKP-A 
A

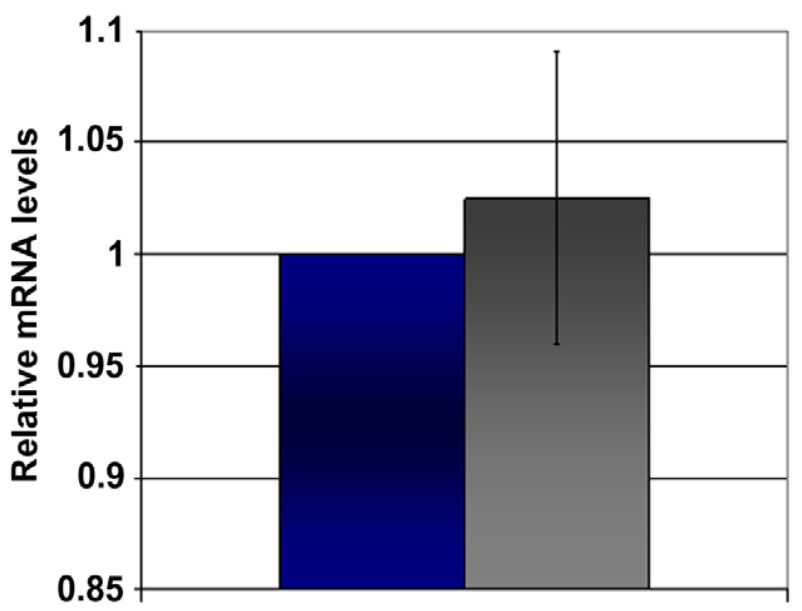

RAN
B

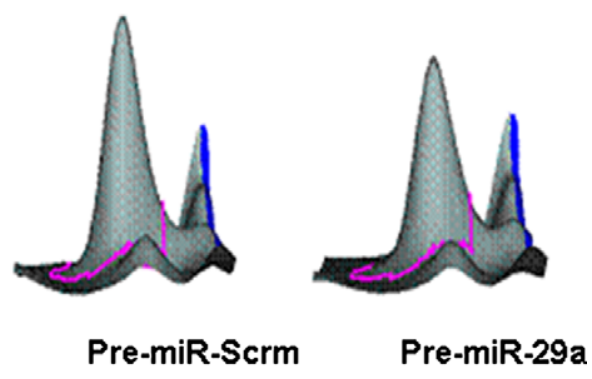

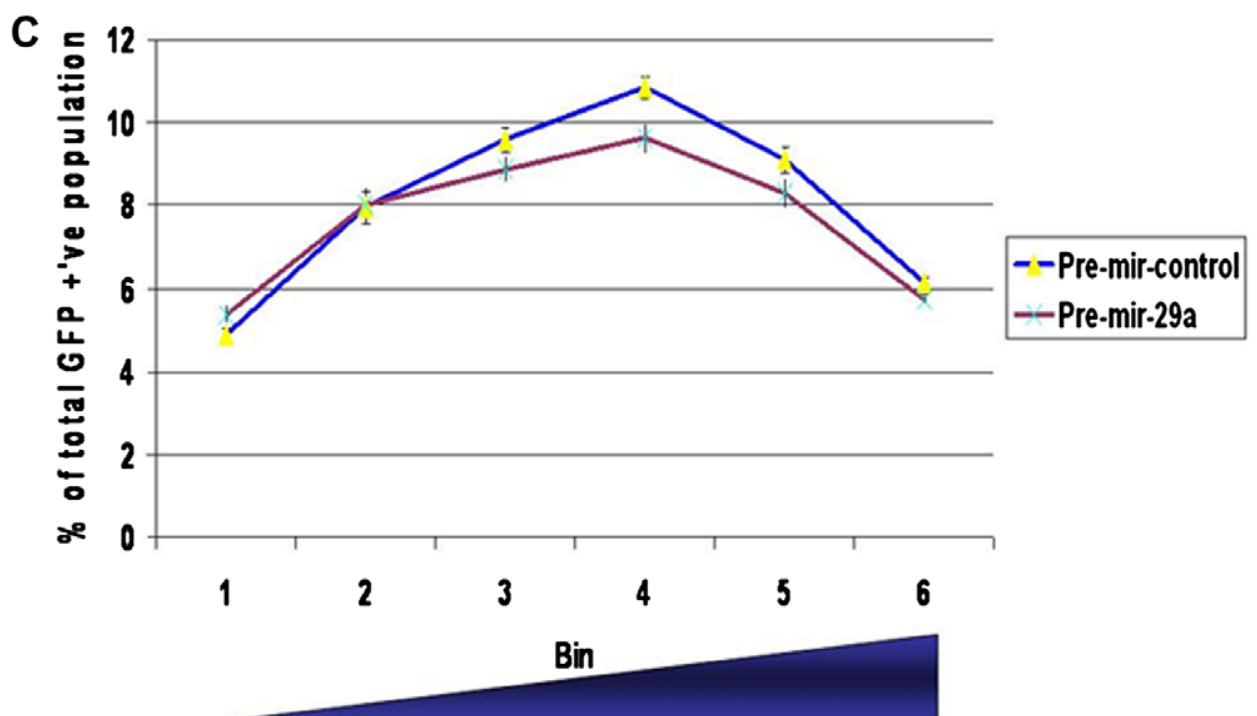

Fluorescence Intensity

Fig. 6 - (A) Transient transfection of DLKP-A cells with pre-miR-29a has no impact on cellular levels of RAN mRNA compared to negative pre-mir control treatment $( \pm S E, n=3)$. (B) 3-D spot image of same samples analysed by $2 D$ DIGE, the quantity of RAN protein is reduced by $>30 \%(p<0.05)$. (C) Flow cytometric analysis of GFP fluorescence in mixed, stable, GFP-3' UTR ${ }^{\mathrm{RAN}}$ expressing DLKP cells. Each 'bin' represents the cells with similar fluorescent intensities from low to high. ${ }^{1-6}$

cells. In the case of RAN knockdown, the invasiveness was reduced by $40-80 \%$ compared to the invasiveness of the controltransfected cells (Fig. 5a). In addition, cell proliferation was reduced by $30-40 \%$ over a 72 -h period (Fig. $5 b$ ). Knockdown was confirmed at both mRNA and protein levels (Fig. 5c and d). Of the four proteins targeted, only ANXA2 contained a predicted seed region though the RNA hybrid software (http:// bibiserv.techfak.uni-bielefeld.de/rnahybrid/) did reveal a weak target site for miR-29a in the RAN 3' UTR (Fig. 5e).

\subsection{Is RAN a direct target of MiR-29a?}

The classical mode of miRNA action typically inhibits target protein translation without concurrent reduction in mRNA abundance. In DLKP-A cells transfected with miR-29a, no significant change in RAN transcript levels was detected by qPCR (Fig. 6a) despite a $35 \%$ reduction in RAN protein when analysed by 2D DIGE (Fig. 6b). Western blots on the same samples could not reproducibly demonstrate this change in RAN expression (data not shown) as this method lacks the sensitivity of the 2D DIGE approach. Having made the connection between miR-29a expression levels, RAN expression and the invasive phenotype, we wished to establish whether miR-29a impacted on RAN expression by direct interaction with the mRNA transcript. The RAN 3' UTR sequence was cloned by PCR from DLKP genomic DNA and placed downstream of a GFP reporter gene. DLKP-A cells, stably expressing this GFP$3^{\prime} \mathrm{UTR}^{\mathrm{RAN}}$ reporter fusion, were generated and transiently 


\begin{tabular}{|c|c|c|c|c|}
\hline Molecular function & Count & $\%$ & $p$-Value & GeneBank accession no. \\
\hline Peroxidase & 4 & 7.27 & 7.18E-04 & NM_006793, NM_005809, NM_002574, NM_004905 \\
\hline Oxidoreductase & 7 & 12.73 & 0.003381 & $\begin{array}{l}\text { NM_152740, NM_000454, NM_006793, NM_005809, } \\
\text { NM_004544, NM_002574, NM_004905 }\end{array}$ \\
\hline $\begin{array}{l}\text { Transfer/carrier } \\
\text { protein }\end{array}$ & 6 & 10.91 & 0.00479 & $\begin{array}{l}\text { NM_015917, NM_001444, NM_018947, NM_002567, } \\
\text { NM_001002858, NM_000700 }\end{array}$ \\
\hline $\begin{array}{l}\text { Serine protease } \\
\text { inhibitor }\end{array}$ & 11 & 20.00 & 0.005989 & $\begin{array}{l}\text { NM_015917, NM_016045, NM_021130, NM_002305, } \\
\text { NM_002796, NM_001008216, NM_024339, NM_002791, } \\
\text { NM_002086, NM_002794, NM_002787 }\end{array}$ \\
\hline $\begin{array}{l}\text { Non-receptor serine/ } \\
\text { threonine protein } \\
\text { kinase }\end{array}$ & 15 & 27.27 & 0.033791 & $\begin{array}{l}\text { NM_000485, NM_006817, NM_002796, NM_152265, } \\
\text { NM_002075, NM_000975, NM_014362, NM_014412, } \\
\text { NM_015917, NM_001540, NM_002415, NM_005809, } \\
\text { NM_002629, NM_175054, NM_002794 }\end{array}$ \\
\hline Other transferase & 4 & 7.27 & 0.035344 & NM_015917, NM_016045, NM_001696, NM_014362, \\
\hline Annexin & 4 & 7.27 & 0.039542 & NM_198175, NM_001002858, NM_005101, NM_000700 \\
\hline $\begin{array}{l}\text { Non-motor actin- } \\
\text { binding protein }\end{array}$ & 13 & 23.64 & 0.042818 & $\begin{array}{l}\text { NM_006817, NM_001008216, NM_000975, NM_014362, } \\
\text { NM_002791, NM_002086, NM_005507, NM_001444, } \\
\text { NM_002305, NM_001540, NM_006012, NM_002629, } \\
\text { NM_002787 }\end{array}$ \\
\hline Protease & 5 & 9.09 & 0.052485 & $\begin{array}{l}\text { NM_002796, NM_006012, NM_002791, NM_002794, } \\
\text { NM_002787 }\end{array}$ \\
\hline Chaperone & 3 & 5.45 & 0.058427 & NM_001540, NM_002013, NM_003372 \\
\hline Other isomerase & 4 & 7.27 & 0.078832 & NM_021130, NM_000194, NM_002572, NM_002013 \\
\hline Neuropeptide & 4 & 7.27 & 0.091305 & NM_015917, NM_002567, NM_002075, NM_014362 \\
\hline Other proteases & 4 & 7.27 & 0.096733 & NM_002796, NM_002791, NM_002794, NM_002787 \\
\hline
\end{tabular}

transfected with pre-miR-29a or control negative sequence. Flow cytometry analysis revealed that the mean cell fluorescence was not significantly impacted across this mixed population of stable cells in response to pre-miR-29a transfection (Fig. 6c).

\section{Discussion}

Several recent publications have established $m i R-29$ family members as important molecules in suppressing tumourigenic phenotypes in cell line models. In vivo, their expression levels have been shown to positively correlate with favourable outcome in AML patients. ${ }^{6}$ Though several important target genes have been identified, typically by homology-based analysis of 3'UTR regions, it is expected that most miRNAs have the potential to influence the expression of many, if not hundreds of target proteins. The list of potential targets identified in this study provides some interesting clues to the different pathways and functions that miR-29a might impact on in its role as an 'anti-oncomir'.

Having established that miR-29a was down-regulated in invasive lung and pancreatic cell lines, we observed a significant reduction in this phenotype upon re-introduction of exogenous $m i R-29 a$. Though upregulation of $m i R-29 a$ has been shown to decrease the tumourigenic potential of A549 cells ${ }^{4}$ this is the first demonstration of a role in modulating the in vitro invasive ability of cancer cells. In addition the effect is not cell- or organ-type specific having demonstrated functional impact in both lung and pancreatic cancer cell lines. Mott and colleagues described a functional role for miR-29b in chologiocarcinomas where its enforced expression reduced the cellular levels of Mcl-1 and sensitised cells to TRAIL-mediated cytotoxicity. ${ }^{3}$ Furthermore, Pekarsky and colleagues provide evidence that $m i R-29 b$ is involved in suppressing expression of the Tcl1 oncogene which is a causal agent in CLL. $^{7}$

We have shown that invasive DLKP-A cells that stably overexpressed miR-29a were also found to have reduced proliferation compared to their control-transfected counterparts and this might be, in part, explained by the ability of miR-29 family members to down regulate Mcl-1 activity.

The 2D DIGE analysis demonstrated that modifying the cellular concentration of miR-29a impacted on the levels of a large number of proteins, with diverse cellular functions. Two lists of differentially expressed proteins were generated using this approach. In an attempt to focus on direct targets of miR-29a we limited our analysis to the proteins up-regulated after anti-mir treatment and down-regulated after premir transfection - referred to as the primary list. The assumption here was that the reciprocally effected proteins must be secondary downstream targets of action. Of course further proof would be required to demonstrate that the transcripts coding for the proteins on the primary list are actually directly bound by miR-29a.

Using the 'RNA hybrid' software programme to analyse the genes on our primary list, 14 were predicted to contain a 'seed' binding site in their 3 ' UTR (at least 6 nt match between nt2-8 at $5^{\prime}$ end of the miR-29a). This represents less than $20 \%$ of the proteins on the list suggesting that either (a) most of the identified proteins are secondary targets of miR-29a action or (b) a canonical seed region is not imperative for miRNAUTR interaction. 
Ontological analysis of the differentially expressed proteins revealed a bias towards 4-5 main biological functions including proliferation, apoptosis, motility, differentiation and mutagenesis (Table 1). Likewise, analysis of the main groupings according to molecular function demonstrated an enrichment of peroxidase and oxidoreductase activities (Table 2), again in keeping with previous reports of association of these types of proteins with metastatic tumour formation. ${ }^{15,16}$ The predominance of these groupings is in keeping with a role for miR-29a in modulating the aggressiveness/invasive potential of cancer cell lines and possibly tumours in vivo. Several of the genes identified have welldocumented roles in stimulating cellular invasion, such as MIF (macrophage migratory inhibitory factor) which has been implicated in prostate, colon and other cancer types. ${ }^{17,18}$ GRB2 (growth factor receptor-bound protein 2) is a crucial adaptor protein that mediates cell signalling from the surface membrane receptors to their downstream targets and indeed is a current target for the development of anticancer therapeutics. ${ }^{19,20}$ It was interesting to observe that, despite being identified in the proteomic analysis, subsequent qPCR analyses of both miR-29a-transfected and untransfected cells indicated extremely low levels of GRB2 transcript (data not shown).

Several peroxiredoxin family members were identified as being down-regulated in response to $m i R-29 a$ transfection supporting several reports correlating their expression with cancer development and recurrence. ${ }^{21,22}$ As antioxidants these proteins might be expected to play a protective role against elimination of cancerous cells in vivo.

Enolase (ENO1) is another protein with a recognised role in cellular invasion as a plasminogen-binding receptor. ${ }^{23}$ Intriguingly, an alternative splice-variant of this gene, cmyc-promoter binding protein, acts as a transcriptional repressor of c-myc which in turn has been shown recently to repress expression of $m i R-29 a .^{8}$ More recently, ENO1 has also been shown to suppress the Notch1 receptor/YY1-dependent activation of c-myc. ${ }^{24}$ These observations suggest the possibility of a feedback loop where increased c-myc expression reduces $m i R-29 a$ levels hence releasing a translational block on ENO1 which in turn antagonises the activation of c-myc, thereby releasing miR-29a expression and so on.

SFRS1 (splicing factor, arginine/serine-rich 1) was found to be decreased in Herceptin-treated ErbB2-overexpressing cell lines and was also shown to affect cellular motility. ${ }^{25,26}$ Our analysis also reveals a predicted miR-29a binding site in the 3' UTR of SFRS1. Galectin-1 (LGALS1) has an established role in the invasive and metastatic potentials of cells in vitro and in vivo. ${ }^{27,28}$ Interestingly there were also examples of genes identified here that have previously been associated with reduction of this phenotype or negatively correlating with poor outcome in clinical studies. Both annexins A1 and A2 are identified as miR-29a-regulated genes in this study and both have previously been shown to reduce cell migration in vitro and to be lost in some nodal metastases. ${ }^{29,30}$ Indeed ANXA2 has a predicted 6 t seed match in its $3^{\prime}$ UTR. The same is true of RKIP (Raf-1 kinase inhibitory protein) which is typically reported to have a metastasis-suppressor role in tumours. ${ }^{31}$ However, most of the proteins that have already been linked to cancer or invasion would be expected to be up-regulated based on the reports in the literature in this phenotype supporting the theory of an anti-invasive role for miR-29a in cells.

Rather than focusing solely on the genes that contained predicted miR-29a target sites in their $3^{\prime}$ UTRs we chose a small group of targets representing proteins with established roles in the phenotype of interest. Knockdown of the expression levels of these targets individually with siRNA resulted in a phenotypic impact only in the case of RAN (RanGTPase). Indeed the degree to which invasion and proliferation were inhibited in the DLKP-A cells was similar to that observed in the miR-29a stably transfected cells. RAN is a small $25 \mathrm{kDa}$ protein that acts as a mediator of nucleocytoplasmic transport. In the nucleus it is loaded with GTP by the chromatin-associated RCC1 complex allowing it to interact with certain transport partners to shuttle proteins and small RNAs (including miRNAs) out of the nucleus. ${ }^{32}$ It is intriguing to consider the possibility of $m i R-29 a$ self-regulating its cytoplasmic concentration by directly modulating RAN translation. RAN is also involved in nuclear segmentation during mitosis where it directs the assembly of the mitotic spindle. Kurisetty and colleagues have recently demonstrated that RAN overexpression in a non-invasive rat mammary epithelial cell line results in increased anchorage-independent growth, cell attachment, invasion through Matrigel $^{\mathrm{m} 4}$ in vitro and metastasis in rats. ${ }^{33}$ Also, Xia and colleagues found that acute silencing of RAN in various tumour cell types causes aberrant mitotic spindle formation, mitochondrial dysfunction and apoptosis. ${ }^{34}$ This dependency was not reflected in other normal cell types.

Having established that miR-29a influences the cellular concentration of a critical protein that can impact on both invasion and proliferation we wanted to establish whether the RAN transcript was a direct target of miR-29a action. The observation that the average fluorescence signal in cells stably expressing a GFP reporter gene fused to the Ran $3^{\prime}$ UTR was not significantly reduced suggests that the impact on endogenous Ran protein expression (35\% down-regulated in proteomics analysis) might be secondary to the effect of miR-29a.

Irrespective of whether RAN is a direct or indirect target of miR-29a activity we provide evidence suggesting that it is via this mechanism, in part at least, that miR-29a influences the invasive and proliferative capacity of cancer cells. Indeed, the RAN-dependent status of many tumours ${ }^{34}$ raises the possibility of augmenting miR-29a expression as a potential therapeutic intervention.

\section{Conflict of interest statement}

None declared.

\section{Acknowledgements}

This work was supported by the Higher Education Authority of Ireland via its PRTLI III funding scheme and by Science Foundation Ireland. 


\section{R E F E R E N C E S}

1. Ma L, Weinberg RA. Micromanagers of malignancy: role of microRNAs in regulating metastasis. Trend Genet 2008;24:448-56.

2. Crawford M, Brawner E, Batte K, et al. MicroRNA-126 inhibits invasion in non-small cell lung carcinoma cell lines. Biochem Biophys Res Commun 2008;373:607-12.

3. Mott JL, Kobayashi S, Bronk SF, Gores GJ. MiR-29 regulates Mcl-1 protein expression and apoptosis. Oncogene 2007;13: 6133-40.

4. Fabbri M, Garzon R, Cimmino A, et al. MicroRNA-29 family reverts aberrant methylation in lung cancer by targeting DNA methyltransferases 3A and 3B. Proc Natl Acad Sci USA 2007;104:15805-10.

5. Baek D, Villén J, Shin C, et al. The impact of microRNAs on protein output. Nature 2008;455:64-71.

6. Garzon R, Garofalo M, Martelli MP, et al. Distinctive microRNA signature of acute myeloid leukemia bearing cytoplasmic mutated nucleophosmin. Proc Natl Acad Sci USA 2008;105:3945-50.

7. Pekarsky Y, Santanam U, Cimmino A, et al. Tcl1 expression in chronic lymphocytic leukemia is regulated by miR-29 and miR-181. Cancer Res 2006;66:11590-3.

8. Chang TC, Yu D, Lee YS, et al. Widespread microRNA repression by Myc contributes to tumorigenesis. Nat Genet 2008;40:43-50.

9. Cleary I, Doherty G, Moran E, Clynes M. The multidrugresistant human lung tumour cell line, DLKP-A10 expresses novel drug accumulation and sequestration systems. Biochem Pharmacol 1997;53:1493-502.

10. Pierce A, Barron N, Linehan R, et al. Identification of a novel, functional role for S100A13 in invasive lung cancer cell lines. Eur J Cancer 2008;44:151.

11. Meleady P, Henry M, Gammell P, et al. Proteomic profiling of CHO cells with enhanced rhBMP-2 productivity following coexpression of PACEsol. Proteomics 2008;8:2611-24.

12. van Rooij E, Sutherland LB, Thatcher JE, et al. Dysregulation of microRNAs after myocardial infarction reveals a role of miR-29 in cardiac fibrosis. Proc Natl Acad Sci USA 2008;105:13027-32.

13. Gebeshuber CA, Zatloukal K, Martinez J. MiR-29a suppresses tristetraprolin, which is a regulator of epithelial polarity and metastasis. ЕMBO Rep 2009;10:400-5.

14. Park SY, Lee JH, Ha M, Nam JW, Kim VN. MiR-29 miRNAs activate p53 by targeting p85 alpha and CDC42. Nat Struct Mol Biol 2009;16:23-9.

15. Nishikawa $M$, Hashida M. Inhibition of tumour metastasis by targeted delivery of antioxidant enzymes. Expert Opin Drug Deliv 2006;3:355-69.

16. Nishikawa M. Reactive oxygen species in tumor metastasis. Cancer Lett 2008;18:53-9.

17. Sun B, Nishihira J, Yoshiki T, et al. Macrophage migration inhibitory factor promotes tumor invasion and metastasis via the Rho-dependent pathway. Clin Cancer Res 2005;11:1050-8.
18. Meyer-Siegler KL, Iczkowski KA, Leng L, Bucala R, Vera PL. Inhibition of macrophage migration inhibitory factor or its receptor (CD74) attenuates growth and invasion of DU-145 prostate cancer cells. J Immunol 2006;177:8730-9.

19. Giubellino A, Burke Jr TR, Bottaro DP. Grb2 signaling in cell motility and cancer. Expert Opin Ther Targets 2008;12: 1021-33.

20. Giubellino A, Gao Y, Lee S, et al. Inhibition of tumor metastasis by a growth factor receptor bound protein $2 \mathrm{Src}$ homology 2 domain-binding antagonist. Cancer Res 2007;67:6012-6.

21. Quan C, Cha EJ, Lee HL, et al. Enhanced expression of peroxiredoxin I and VI correlates with development, recurrence and progression of human bladder cancer. J Urol 2006;175:1512-6.

22. Kim JH, Bogner PN, Baek SH, et al. Up-regulation of peroxiredoxin 1 in lung cancer and its implication as a prognostic and therapeutic target. Clin Cancer Res 2008;14:2326-33.

23. Liu KJ, Shih NY. The role of enolase in tissue invasion ad metastasis of pathogens and tumour cells. J Cancer Mol 2007;3:45-8

24. Hsu KW, Hsieh RH, Lee YH, et al. The activated Notch1 receptor cooperates with alpha-enolase and MBP-1 in modulating c-myc activity. Mol Cell Biol 2008;28:4829-42.

25. Mukherji M, Brill LM, Ficarro SB, Hampton GM, Schultz PG. A phosphoproteomic analysis of the ErbB2 receptor tyrosine kinase signaling pathways. Biochemistry 2006;45: 15529-40.

26. Ghigna C, Giordano S, Shen $\mathrm{H}$, et al. Cell motility is controlled by SF2/ASF through alternative splicing of the Ron protooncogene. Mol Cell 2005;20:881-90.

27. Jung TY, Jung S, Ryu HH, et al. Role of galectin-1 in migration and invasion of human glioblastoma multiforme cell lines. $J$ Neurosurg 2008;109:273-84.

28. Rorive S, Belot N, Decaestecker C, et al. Galectin-1 is highly expressed in human gliomas with relevance for modulation of invasion of tumor astrocytes into the brain parenchyma. Glia 2001;33:241-55.

29. Tatenhorst L, Rescher U, Gerke V, Paulus W. Knockdown of annexin 2 decreases migration of human glioma cells in vitro. Neuropathol Appl Neurobiol 2006;32:271-7.

30. Yu G, Wang J, Chen Y, et al. Tissue microarray analysis reveals strong clinical evidence for a close association between loss of annexin A1 expression and nodal metastasis in gastric cancer. Clin Exp Metastasis 2008;25:695-702.

31. Granovsky AE, Rosner MR. Raf kinase inhibitory protein: a signal transduction modulator and metastasis suppressor. Cell Res 2008;18:452-7.

32. Clarke PR, Zhang C. Spatial and temporal coordination of mitosis by Ran GTPase. Nat Rev Mol Cell Biol 2008;9:464-77.

33. Kurisetty VV, Johnston PG, Johnston N, et al. RAN GTPase is an effector of the invasive/metastatic phenotype induced by osteopontin. Oncogene 2008;27:7139-49.

34. Xia F, Lee CW, Altieri DC. Tumor cell dependence on Ran-GTPdirected mitosis. Cancer Res 2009;68:1826-33. 